\title{
Strategies for Reduced Cooling Time of Asphalt for Airfield Pavement Overlay
}

\author{
Taqia Rahman ${ }^{1}$; Nick Thom²; Andrew Dawson ${ }^{3}$ \\ ${ }^{1}$ Lecturer, Universitas Gadjah Mada, Jl. Grafika No. 2, Kampus UGM, Yogyakarta \\ 55281, Indonesia. Email: taqia.rahman@ugm.ac.id \\ ${ }^{2}$ Assistant Professor, the University of Nottingham, University Park, Nottingham \\ NG7 2RD, UK. Email: nicholas.thom@nottingham.ac.uk \\ ${ }^{3}$ Associate Professor, the University of Nottingham, University Park, Nottingham \\ NG7 2RD, UK. Email: andrew.dawson@ nottingham.ac.uk
}

\begin{abstract}
Reducing the cooling period of newly laid asphalt overlays could help airport authorities to quickly open remediated pavements to traffic. This paper reviews four strategies for a reduced cooling period, prior to trafficking, of newly-placed asphalt overlays: (1) Defining and selecting the warmest permissible asphalt temperature at opening to traffic, (2) Reducing the cooling time by using warm mix asphalt (WMA), (3) Increasing the cooling rate of asphalt by using high thermal conductivity material, and (4) Decreasing the pavement temperature by spraying water onto the freshly paved asphalt. A one-dimensional (1D) heat-transfer model using a finite element (FE) solution is developed as a function of weather conditions to simulate the effect of each strategy on asphalt cooling time. The analysis shows that each strategy significantly contributes to the rapid cooling of newly laid asphalt. However, there are some concerns over the performance of the pavements when some strategies are adopted.
\end{abstract}

\section{INTRODUCTION}

A large number of scheduled flights at major civil airports has made it necessary that runway repair and overlay be carried out without interfering with flight schedules. Using hot mix asphalt (HMA) during the nighttime has become one practical solution to this issue. Table 1 shows information of several airfield pavement rehabilitations performed during off-peak times. Using this method, the runway is closed at night for several hours and immediately opened to aircraft traffic in the morning. Wills (1982) recommended 7 hours as the minimum working hours for contractors during the offpeak period. However, the available time tends to be more limited recently due to airport operations, as noted by White (2017) in large Australian airports. The construction period appears to have shifted from 6-8 to 4-5 hours in the last 10 years.

At the end of the work time frame, contractors should allow several hours for cooling of newly placed asphalt before traffic opening. Shortening this cooling time would allow airport authorities to quickly open the new pavement to traffic and/or allow contractors to place the maximum amount of HMA each night. Thus rapid asphalt pavement construction could nightly increase the pavement target length to be paved, thus shortening the overall contract. This research aims to investigate strategies for reducing cooling time of new asphalt to accelerate airport pavement construction. 
Table 1. Several airports in the world with rehabilitation during the off-peak period

\begin{tabular}{|c|c|c|c|c|c|}
\hline No & Sites (Airports) & Year & Scope of works & $\begin{array}{l}\text { Total Asphalt } \\
\text { production } \\
\text { (tonnes) }\end{array}$ & $\begin{array}{c}\text { Available } \\
\text { construction } \\
\text { time per night }\end{array}$ \\
\hline 1 & $\begin{array}{l}\text { London Heathrow } \\
\text { (LHR), UK }\end{array}$ & 2013 & $\begin{array}{l}\text { Milling and replacing } 50 \mathrm{~mm} \text { runway } \\
\text { surface with asphalt, runway } \\
\text { lighting, and paint marking in the } \\
\text { Southern Runway }(50 \mathrm{~m} \times 3,658 \mathrm{~m})^{b}\end{array}$ & $21,000^{\mathrm{b}}$ & $\begin{array}{c}7.5 \text { hours }{ }^{\mathrm{a}} \\
(10.30 \mathrm{pm}- \\
6 \mathrm{am})\end{array}$ \\
\hline 2 & $\begin{array}{l}\text { Brisbane (BNE), } \\
\text { Australia }\end{array}$ & 2013 & $\begin{array}{l}275,000 \mathrm{~m}^{2} \text { asphalt overlay at BNE } \\
\text { runway } 01-19 \text {, and new installation } \\
\text { of ground lighting }{ }^{\mathrm{c}}\end{array}$ & $18,000^{\mathrm{c}}$ & $\begin{array}{c}6 \text { hours }^{\mathrm{c}} \\
(11 \mathrm{pm}-5 \mathrm{am})\end{array}$ \\
\hline 3 & $\begin{array}{l}\text { Fukuoka (FUK), } \\
\text { Japan } \mathrm{g}\end{array}$ & $2000-2002$ & $\begin{array}{l}\text { Removing the } 150 \mathrm{~mm} \text {-layer and } \\
\text { resurfacing the layer of runway with } \\
60 \mathrm{~m} \text { wide and } 2,800 \mathrm{~m} \text { long }{ }^{\mathrm{g}}\end{array}$ & - & $\begin{array}{c}7 \text { hours } \mathrm{g} \\
(11 \mathrm{pm}-6 \mathrm{am})\end{array}$ \\
\hline 4 & $\begin{array}{l}\text { Ronald Reagan } \\
\text { Washington National } \\
\text { (DCA), USA }\end{array}$ & 2011 & $\begin{array}{l}75 \mathrm{~mm} \text { mill and replacement of } \\
\text { pavement at Runway } 1-19 \text { and } \\
\text { reinstalling new lighting system }\end{array}$ & - & $\begin{array}{c}7 \text { hours }^{j} \\
(11 \mathrm{pm}-6 \mathrm{am})\end{array}$ \\
\hline 5 & $\begin{array}{l}\text { Jakarta Airports } \\
(\mathrm{CGK}) \text {, Indonesia }\end{array}$ & 2017-now & $\begin{array}{l}19 \mathrm{~cm} \text { asphalt overlay for the main } \\
\text { runway }(60 \mathrm{~m} \times 3,600 \mathrm{~m}) \text {, replacing } \\
\text { runway lighting, paint marking, and } \\
\text { runway shoulder overlay }\end{array}$ & 94,500 & $\begin{array}{c}7 \text { hours } \\
(11 \mathrm{pm}-6 \mathrm{am})\end{array}$ \\
\hline
\end{tabular}

a (Hacan, 2013), ${ }^{\mathrm{b}}$ (Express, 22 Agt 2013), ${ }^{\mathrm{c}}$ (Brisbane-Airport Australia, 25 November 2013), ${ }^{\mathrm{d}}$ (Hobart-Airport, Feb 20, 2012), ${ }^{\mathrm{e}}$ (Fulton Hogan, 2011), ${ }^{\mathrm{f}}$ (McArdle, July 2010), ${ }^{\mathrm{g}}$ Hachiya et al. (2008), ${ }^{\mathrm{h}}$ (Dublin-Airport, 14 November 2016), ${ }^{\mathrm{i}}\left(\right.$ Dublin-Airport, Nov 22, 2017), ${ }^{\mathrm{j}}$ (Frank et al., 2013)

\section{RESEARCH METHODOLOGY}

This research reviews four strategies for a reduced cooling period:

(1) Defining and selecting the warmest asphalt temperature at opening to traffic commensurate with adequate performance and safe operations,

(2) Reducing the cooling time by using warm-mix-asphalt (WMA),

(3) Increasing the cooling rate of asphalt by using high thermal conductivity material,

(4) Decreasing the pavement temperature by spraying water onto the new asphalt.

A one-dimensional (1D) heat-transfer model, using a finite element (FE) program (ABAQUS) was developed to simulate the effect of each strategy on pavement construction time. The model is initially validated against in-situ pavement data collected from several projects in the United States. A wide variety of weather conditions and typical thermal properties of asphalt materials is assumed in this study. The possible drawbacks and risk of the above-mentioned strategies, including potential premature damage of pavement (rutting and delamination), are also reviewed.

\section{OVERVIEW THERMODYNAMIC PROCESS OF NEWLY LAID ASPHALT COOLING}

The cooling response of newly laid asphalt mixture is mainly dominated by the climatic conditions of the locale. This mechanism of heat transport in asphalt pavements is governed by thermodynamic principles (illustrated in Figure 1): conduction, radiation and convection. The heat flux at the top of asphalt pavement comprises the fluxes from the air to the surface by radiation from the sun, convection, and heat diffusion (conduction) into the pavement layers underneath. 
Thermal flux on the surface asphalt pavement was described by Lytton et al. (2010):

$$
\sum Q=Q_{\text {solar }}^{\prime \prime}+Q_{\text {rad }}^{\prime \prime}-Q_{\text {conv }}-Q_{\text {cond }}
$$

where $\sum Q=$ sum of heat flux $(\mathrm{W} / \mathrm{m} 2) ; Q_{\text {solar }}=$ thermal flux from total solar radiation $\left(\mathrm{W} / \mathrm{m}^{2}\right) ; Q_{\text {rad }}^{\prime \prime}=$ thermal radiation $\left(\mathrm{W} / \mathrm{m}^{2}\right) ; Q_{c o n v}=$ thermal convection between the pavement and the surroundings $\left(\mathrm{W} / \mathrm{m}^{2}\right)$; and $Q_{\text {cond }}=$ thermal conduction at the surface of pavement $\left(\mathrm{W} / \mathrm{m}^{2}\right)$.

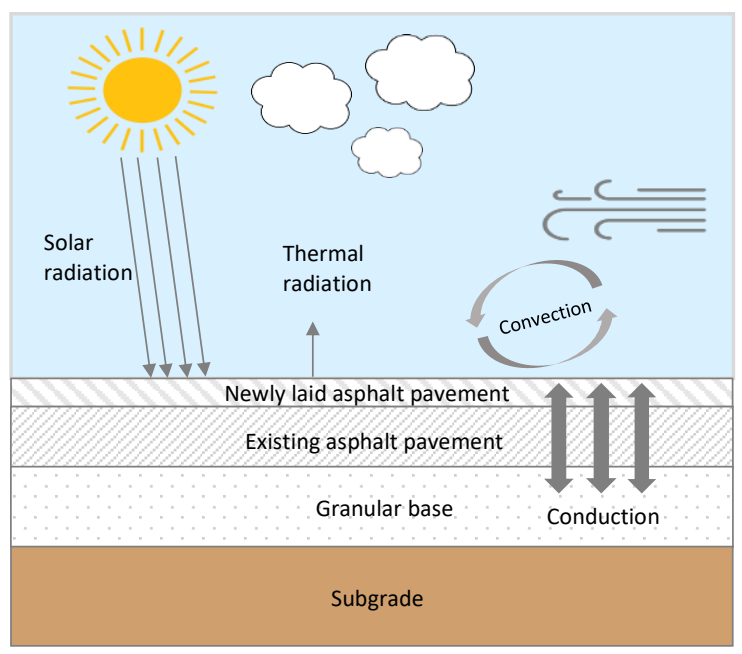

Figure 1. Model of heat transport in newly laid asphalt pavement and its surroundings.

\section{Solar Radiation}

The solar radiation thermal flux, $Q_{\text {solar }}^{\prime \prime}$, is the sum of solar radiation received by the surface of asphalt and defined as follows (Han et al., 2011, Bergman et al., 2011):

$$
Q_{\text {solar }}^{\prime \prime}=Q_{\text {solar }}-\tilde{\alpha} Q_{\text {solar }}=(1-\tilde{\alpha}) Q_{\text {solar }}
$$

Where $\tilde{\alpha}=$ the albedo, a measure of how reflective a surface is ( $\tilde{\alpha}=0.04$ for asphalt); $\tilde{\alpha} Q_{\text {solar }}=$ quantity of the solar radiation reflected by the asphalt surface $\left(\mathrm{W} / \mathrm{m}^{2}\right)$.

\section{Thermal Radiation}

Thermal radiation, $Q_{\text {rad }}^{\prime \prime}$, is the electromagnetic radiation reflected from a surface due to its temperature. It contains the incoming $\left(Q_{\text {in }}\right)$, and outgoing, $\left(Q_{\text {out }}\right)$ long-wave radiation from the atmosphere to the asphalt surface and back. It is determined as follows (Hermansson, 2004, Han et al., 2011, Solaimanian and Kennedy, 1993):

$$
Q_{\text {rad }}^{\prime \prime}=Q_{\text {in }}-Q_{\text {out }}=\varepsilon_{a} \sigma T_{a}^{4}-\sigma \varepsilon T_{s}^{4}
$$

where $Q_{\text {in }}=$ incoming wave radiation heat flow from the asphalt surface; $Q_{\text {out }}=$ outgoing long-wave radiation heat flow from the atmosphere; $\sigma=$ Stefan-Boltzmann constant $\left(5.67 \times 10^{-8} \mathrm{Wm}^{-2} \mathrm{~K}^{-4}\right) ; \varepsilon_{a}=$ absorption coefficient of the surface; $\varepsilon=$ emissivity of the surface; $T_{a}=$ air temperature $(\mathrm{K})$; and $T_{s}=$ surface temperature $(\mathrm{K})$.

\section{Conduction}

The heat conduction of heat within newly laid asphalt and its underlying layers is assumed to be governed by the Fourier law (Rohsenow et al., 1998):

$$
Q_{\text {cond }}=-k \frac{\partial T}{\partial x}
$$


where $k=$ the thermal conductivity of asphalt mixture $(\mathrm{W} / \mathrm{m} \cdot \mathrm{K}) ; \delta T=$ temperature different $(\mathrm{K})$; and $\delta x=$ thickness of asphalt pavement in the heat transfer direction $(\mathrm{m})$.

\section{Convection}

Cooling of the newly laid asphalt primarily occurs by convection of heat flux between the asphalt surface and the air. The rate of heat transport by convection is defined by 'Newton's law of cooling' below (Rohsenow et al., 1998):

$$
Q_{\text {conv }}=h_{c}\left(T_{s}-T_{\infty}\right)
$$

where $h_{c}=$ heat transfer coefficient $\left(\mathrm{W} / \mathrm{m}^{2} \cdot \mathrm{K}\right) ; T_{s}=$ pavement surface temperature $(\mathrm{K})$; and $T_{\infty}=$ fluid temperature (K). The $h_{c}$ can be estimated from empirical equations. The empirical equation used in this study is Jurges model (Wang et al., 2014):

$$
h_{c}=5.8+4.1 v_{w}
$$

where $v_{w}=$ wind speed $(\mathrm{m} / \mathrm{s})$.

\section{CALCULATION OF COOLING RESPONSE OF ASPHALT BY FEM}

\section{Finite Element Model Development}

A simplified one-dimensional heat transport model of the asphalt pavement structure was developed in ABAQUS, a general purpose FE software. The thermal transient analyses are carried out to investigate the temperature change of newly laid asphalt overlay for different climatic conditions, construction times and material properties. The multi-layered pavement structure, including asphalt overlay, existing asphalt, granular base course and subgrade are modelled by 4-node linear heat transfer quadrilateral elements (DC2D4). Model geometry, including layer thicknesses and boundary conditions, is presented in Figure 2. The thickness of each layer is based on the typical pavement structure commonly used at airports. The absorbed radiation (including atmospheric and solar radiation), emitted radiation and convective heat transfer at the surface of asphalt pavement is considered. The bottom boundaries are far from the asphalt. Hence its boundary condition is assumed to be a constant temperature; whereas the right and left boundaries are assumed to be thermally insulated. The thermal properties of pavement materials are presented in Table 2 .

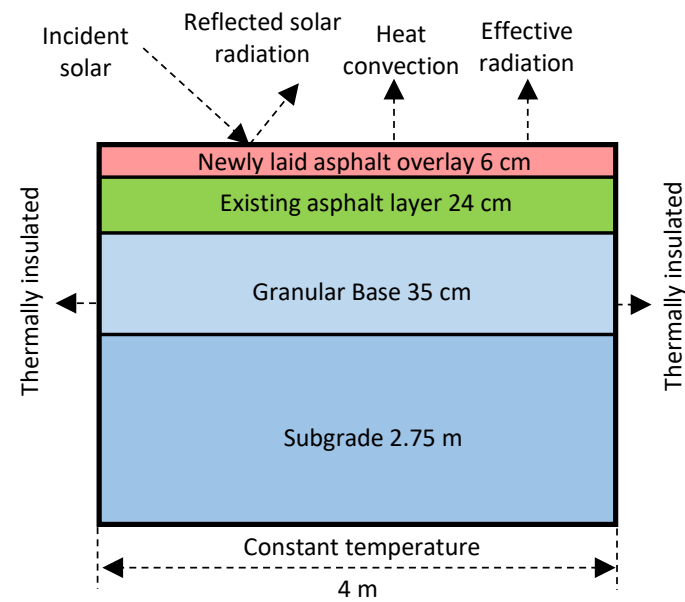

Table 2. Thermo-physical properties of material used for the model.

Figure 2. Asphalt pavement structure layout for cooling pavement prediction.

\begin{tabular}{|l|c|c|c|}
\hline $\begin{array}{l}\text { Materials } \\
\text { types }\end{array}$ & $\begin{array}{c}\text { Thermal } \\
\text { conductivity, } \\
k \text { (W/K.m) }\end{array}$ & $\begin{array}{c}\text { Specific } \\
\text { heat, } C \\
(\mathrm{~W} . \mathrm{s} / \mathrm{kg} . \mathrm{K})\end{array}$ & $\begin{array}{c}\text { Density } \\
\left(\mathrm{kg} / \mathrm{m}^{3}\right)\end{array}$ \\
\hline $\begin{array}{l}\text { Asphalt } \\
\text { overlay }\end{array}$ & 1.5 & 850 & 2450 \\
\hline $\begin{array}{l}\text { Existing } \\
\text { asphalt }\end{array}$ & 1.5 & 860 & 2350 \\
\hline Base-layer & 1.5 & 805 & 2300 \\
\hline Subgrade & 1.79 & 1100 & 2200 \\
\hline
\end{tabular}


Figure 3(a) presents a graphic of the FE model demonstrating the pavement temperature contour 9 mins after placing. This predicted temperature of freshly laid asphalt overlay at different times and depths are extracted and plotted in Figure 3(b). It reveals that the temperature at the bottom of the overlay drops quickly at the beginning because of its direct contact with the existing asphalt. However, after 60 minutes, the temperature at the bottom of the newly laid asphalt is higher than that in the middle and bottom. The temperature at the bottom of overlay is often the highest value when the pavement cools down. This finding is comparable with the result of a study conducted by Wang et al. (2014) using different FE software. In this study, the temperature at the bottom of the overlay is used as the reference point of asphalt cooling.
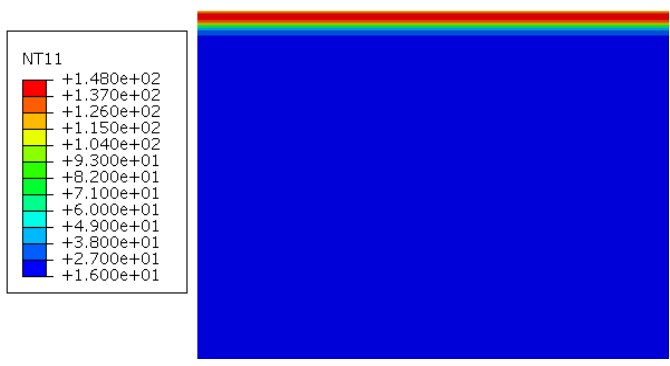

(a)

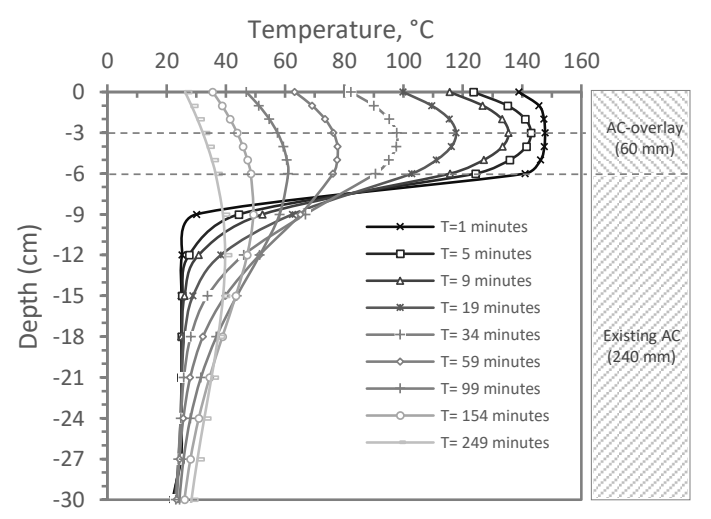

(b)

Figure 3. (a) Typical output of program: pavement temperature contour $\left({ }^{\circ} \mathrm{C}\right)$ (b) Temperature profile of pavement at various time.

\section{Comparison of the FE model and Field Data}

To confirm the accuracy of the output, the FE model was validated against in-situ pavement temperature measurement, collected from four projects in Minnesota, USA, by Chadbourn et al. (1998) in 1996 and 1997 during summer. The project details are presented in Table 3.

Table 3. Asphalt paving conditions for field validation (Chadbourn et al., 1998)

\begin{tabular}{|l|c|c|c|c|}
\hline Input & Site A & Site B & Site C & Site D \\
\hline Location & $\begin{array}{c}\text { Highway 52. } \\
\text { Rosemount, MN }\end{array}$ & $\begin{array}{c}\text { Ipava Avenue, } \\
\text { Lakeville, MN }\end{array}$ & $\begin{array}{c}\text { Ipava Avenue, } \\
\text { Lakeville, MN }\end{array}$ & $\begin{array}{c}2^{\text {nd }} \text { Avenue, } \\
\text { Waite Park, MN }\end{array}$ \\
\hline Date and Time & $\begin{array}{c}12 \text { July 1996, } \\
9: 45 \mathrm{am}\end{array}$ & $\begin{array}{c}13 \text { October 1995, } \\
10: 30 \mathrm{am}\end{array}$ & $\begin{array}{c}14 \text { October } \\
1995,12: 15 \mathrm{pm}\end{array}$ & $\begin{array}{c}16 \text { October 1995, } \\
9: 30 \mathrm{pm}\end{array}$ \\
\hline Air temperature & $19.4^{\circ} \mathrm{C}$ & $16.4^{\circ} \mathrm{C}$ & $15.4^{\circ} \mathrm{C}$ & $3.8^{\circ} \mathrm{C}$ \\
\hline Wind speed & $16 \mathrm{~km} / \mathrm{h}$ & $16 \mathrm{~km} / \mathrm{h}$ & $3 \mathrm{~km} / \mathrm{h}$ & $2 \mathrm{~km} / \mathrm{h}$ \\
\hline Existing surface & $\mathrm{HMA}(\mathrm{dense})$ & Aggregate Base & $\mathrm{HMA}($ dense $)$ & $\mathrm{HMA}(\mathrm{dense})$ \\
\hline Existing surface temp. & $22.7^{\circ} \mathrm{C}$ & $19.4^{\circ} \mathrm{C}$ & $17.8{ }^{\circ} \mathrm{C}$ & $3.1^{\circ} \mathrm{C}$ \\
\hline Cloud cover & $50 \%$ & $0 \%$ & $100 \%$ & $100 \%$ \\
\hline Lift thickness & $64 \mathrm{~mm}$ & $50 \mathrm{~mm}$ & $50 \mathrm{~mm}$ & $60 \mathrm{~mm}$ \\
\hline
\end{tabular}

Using the information in Table 3, analyses were conducted to validate the FE model. The comparisons of the FE model results and in-situ measurements are presented in Figure 4 for temperatures at mid-depth of the asphalt layers. In general, the cooling curve shows a good agreement between the FE model and field measurements, confirming the formers' suitability. 


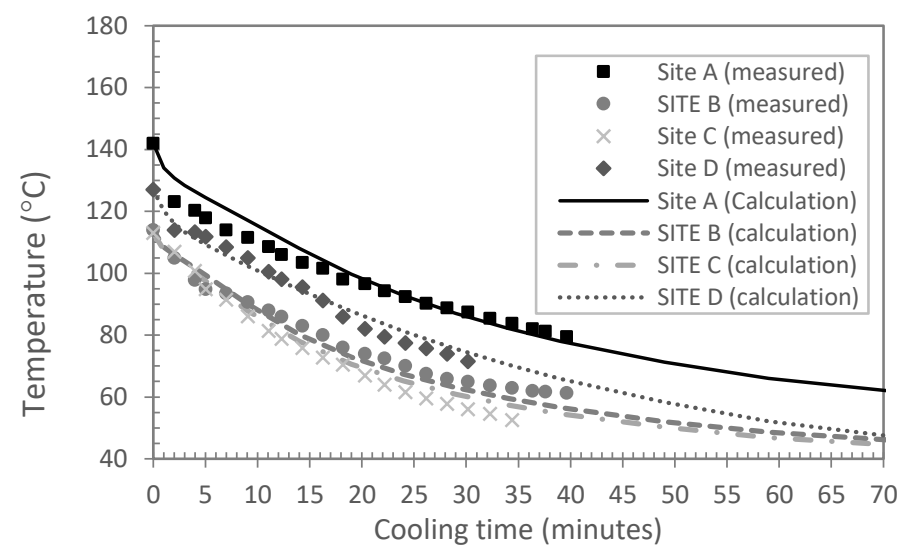

Figure 4. Measured and predicted cooling at mid-depth of a new HMA layer.

\section{STRATEGIES OF RAPID COOLING OF ASPHALT PAVEMENT}

\section{(1) Defining and selecting the warmest asphalt temperature at opening to traffic}

Opening a newly placed asphalt overlay to traffic at higher temperature would allow more asphalt to be paved each night due to the reduced cooling time needed. On the other hand, opening asphalt at high temperature may lead to premature damage, including rutting and shear failure (Figure 5).
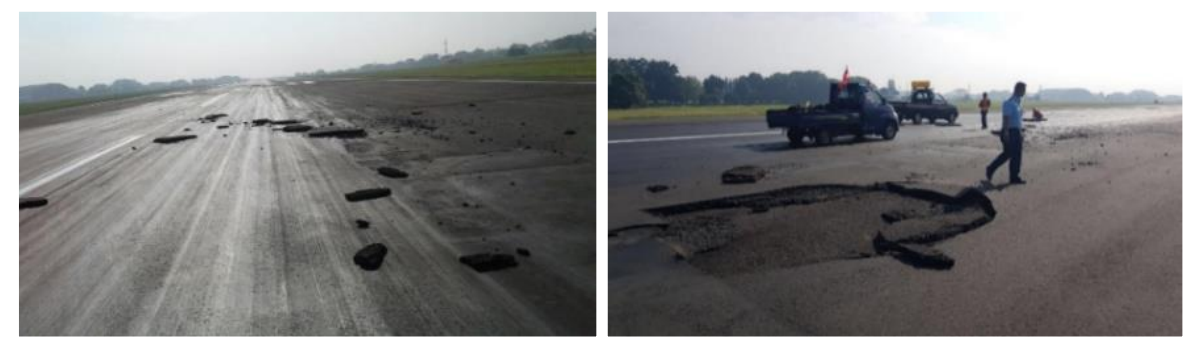

Figure 5. Failure in new asphalt overlay at runway (Courtesy of Indonesia Airport Authority).

According to the specification of the FAA (2006) in the United States, a new pavement surface temperature has to be below $65^{\circ} \mathrm{C}$ before opening to traffic. The specification published by the Japan Civil Aviation Bureau (Hachiya et al., 2008) suggested $50^{\circ} \mathrm{C}$ as the maximum asphalt temperature at opening while Aho et al. (2016) reported that during runway rehabilitation work at Frankfurt Airport in Germany, no damage was observed when the runway was opened to traffic at $85^{\circ} \mathrm{C}$.

The first strategy of reduced asphalt cooling time is to define and select the warmest asphalt temperature. An analysis of cooling time of asphalt with different allowable asphalt overlay temperatures was carried out. Asphalt pavement overlay was assumed to be performed during at night-time. Two project environment locations, tropical and subtropical zone were analysed. The previous heat transfer model displayed in Figure 2 and thermal properties of pavement material from Table 2 were used for this analysis, while the environment condition is shown in Table 4.

The results are shown as cooling time versus the temperature at the bottom of the freshly laid asphalt layer in Figure 6. The graph reveals that the rate of cooling of the asphalt in a typical sub-tropical zone is higher than that in a typical tropical zone. This is as expected, as the lower ambient temperature and higher wind speed in subtropical 
zones will increase the rate of heat loss from hot asphalt. The computed cooling time required to reach different temperatures at opening to traffic is presented in Table 5.

Table 4. Input data for cooling time analysis using ABAQUS

\begin{tabular}{|l|c|c|c|c|}
\hline \multirow{2}{*}{ Location } & \multicolumn{4}{|c|}{ Input } \\
\cline { 2 - 5 } & Air temp. & Wind speed & Existing surface temp. & Delivery temp. \\
\hline Tropical zone & $25^{\circ} \mathrm{C}$ & $3.6 \mathrm{~km} / \mathrm{h}$ & $25^{\circ} \mathrm{C}$ & $148^{\circ} \mathrm{C}$ \\
\hline Sub-tropical zone & $12^{\circ} \mathrm{C}$ & $9 \mathrm{~km} / \mathrm{h}$ & $12^{\circ} \mathrm{C}$ & $148^{\circ} \mathrm{C}$ \\
\hline
\end{tabular}

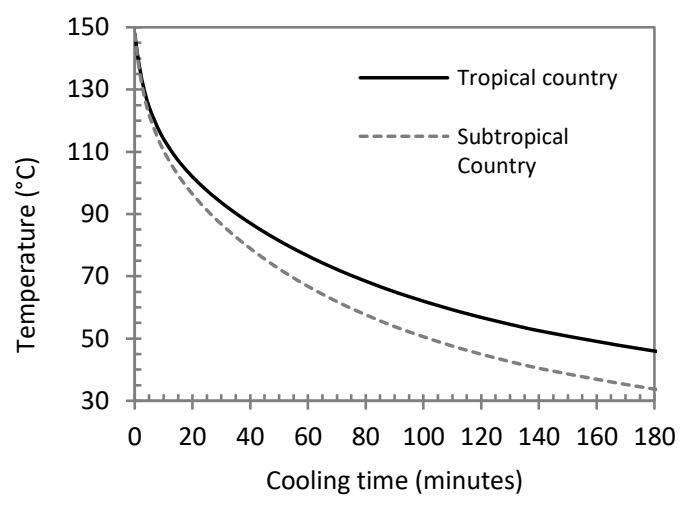

Table 5. Time estimate for HMA to cool lepending on opening to traffic temperature

\begin{tabular}{|l|c|c|c|c|c|c|}
\hline \multirow{2}{*}{ Location } & \multicolumn{5}{|c|}{ Temperature of opening to traffic: } \\
\cline { 2 - 6 } & $85^{\circ} \mathrm{C}$ & $70^{\circ} \mathrm{C}$ & $60^{\circ} \mathrm{C}$ & $50^{\circ} \mathrm{C}$ & $35^{\circ} \mathrm{C}$ \\
\cline { 2 - 6 } Cooling time (minutes) \\
\hline $\begin{array}{l}\text { Tropical } \\
\text { Country }\end{array}$ & 44 & 76 & 107 & 155 & 296 \\
\hline $\begin{array}{l}\text { Subtropical } \\
\text { Country }\end{array}$ & 32 & 54 & 74 & 102 & 173 \\
\hline
\end{tabular}

Figure 6. Cooling of newly laid of asphalt in

Tropical and Sub-tropical Country

Table 5 indicates the sensitivity of time until opening to the selected permissible trafficking temperature. For example, when $70^{\circ} \mathrm{C}$ is set as the maximum asphalt temperature for trafficking, the predicted cooling time is 76 minutes in a tropical country. The cooling time becomes double when $50^{\circ} \mathrm{C}$ is used as the criterion and much longer when a lower temperature for trafficking (for example $35^{\circ} \mathrm{C}$ ) is used as a criterion for airfield opening. What is the warmest permissible asphalt temperature will depend on several factors, including the type of asphalt, air traffic volume and maximum weights of operated aircraft. Defining an optimal temperature will prevent premature damage and allow the earliest opening of the asphalt to traffic.

\section{(2) Reducing the cooling time of freshly placed asphalt by using warm mix asphalt (WMA)}

Warm-mix asphalt (WMA) is generally produced $14^{\circ} \mathrm{C}$ to $50^{\circ} \mathrm{C}$ below that of HMA (West et al., 2014). For airport pavement asphalt overlays, the lower production and placement temperature of WMA mean that less cooling time is required before the overlay reaches a specific temperature and can be opened to traffic, compared to HMA (Su et al., 2009). For this reason, the cooling time of dense-graded HMA and WMA were evaluated in the same way as before, with all the climatic conditions in a typical tropical country being maintained, fixed. The temperature for HMA spreading is $148^{\circ} \mathrm{C}$, whereas it is considered $130^{\circ} \mathrm{C}$ and $118^{\circ} \mathrm{C}$ for WMA. The thermal properties for WMA and HMA are assumed the same. As seen in Figure 7, due to the lower initial temperature, the two WMAs only need 86 and 71 minutes to reach $60^{\circ} \mathrm{C}$ compared with 107 minutes required by the HMA. Thus, from this analysis, the use of WMA would reduce the cooling time. However, it is still questionable whether the temperature of opening to traffic for WMA should be the same as HMA or not. At the same temperature of opening to traffic, the WMA could be more susceptible to rutting due to reduced asphalt binder viscosity. A lower temperature for trafficking would then be needed for the WMA and its early-opening potential weakened. 


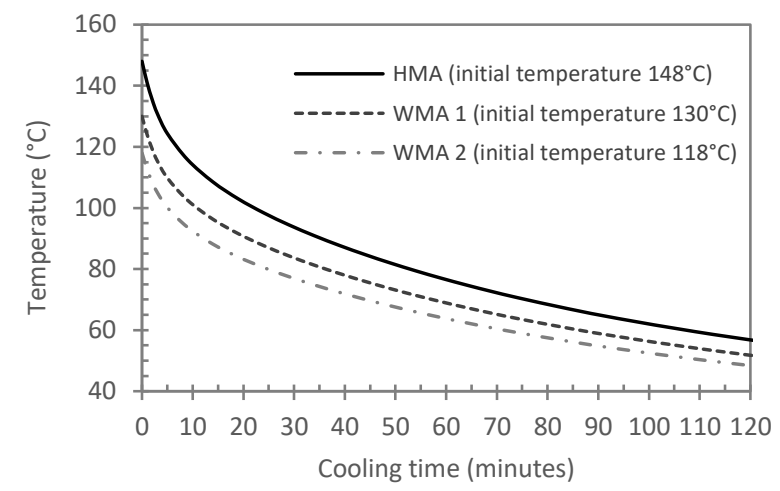

Figure 7. Cooling curve of HMA versus WMA at bottom of newly laid asphalt.

\section{(3) Increasing asphalt cooling rate by use of high thermal conductivity material}

It is hypothesized that the more conductive the asphalt mixture, the quicker the cooling of asphalt mixture due to the high rate of heat flow. Conversely, a higher specific heat $(C)$ of an asphalt material will give it a slower cooling as more energy is stored and must be removed to lower the temperature. In the case of newly laid asphalt, a material with high thermal conductivity and low specific heat will enable a quick opening to traffic. In this study, 3 different levels of thermo-physical properties of asphalt material from various sources (shown in Table 6) were analysed to investigate their effect on asphalt cooling. The typical weather condition in a tropical country during night construction (as presented in Table 4) was used and kept constant throughout.

Table 6. Thermal properties of pavement material.

\begin{tabular}{|l|c|c|c|c|}
\hline \multirow{2}{*}{ Level } & \multicolumn{4}{|c|}{ Thermal material properties } \\
\cline { 2 - 5 } & $\begin{array}{c}\text { Conductivity, } \\
k \text { (W/K.m) }\end{array}$ & Sources & $\begin{array}{c}\text { Specific heat, } \\
C \text { (W.s/kg.K) }\end{array}$ & Sources \\
\hline Low & 0.6 & Hall et al. (2012) & 850 & Wang et al. (2014) \\
\hline Medium & 1.5 & Wang et al. (2014) & 1400 & Zapata and Houston (2008) \\
\hline High & 2.8 & Côté and Konrad (2005) & 2000 & Mrawira and Luca (2006) \\
\hline
\end{tabular}

The cooling results are sketched in Figure 8. The analysis in Figure 8(a) indicates that cooling of asphalt is significantly affected by thermo-physical properties of material. Almost 180 minutes are needed for an asphalt overlay with low thermal conductivity (k) to reach a temperature of $60^{\circ} \mathrm{C}$, whereas 107 minutes is needed for asphalt with medium thermal conductivity and approximately 79 minutes when using high thermal conductivity asphalt material. The cooling of asphalt is also considerably influenced by specific heat $(C)$ of asphalt material as shown in Figure 8(b).

Previous studies show that higher thermal conductivity can be achieved by modifying aggregate, admixtures, density and porosity of asphalt mixture. A study by Dawson et al. (2012) found an increase of thermal conductivity of asphalt by about $135 \%$ by replacing limestone aggregates with quartzite for asphalt mixtures. The same study showed that the addition of copper fibres to asphalt mixtures enhanced the thermal conductivity of asphalt only by about $13 \%$. Meanwhile, a study by Côté and Konrad (2005) indicated that thermal conductivity of asphalt increases with an increase in density and decrease of porosity (air voids). Therefore, some modification to mixes may be practical, whilst others seem to be of little value and/or uneconomic. 


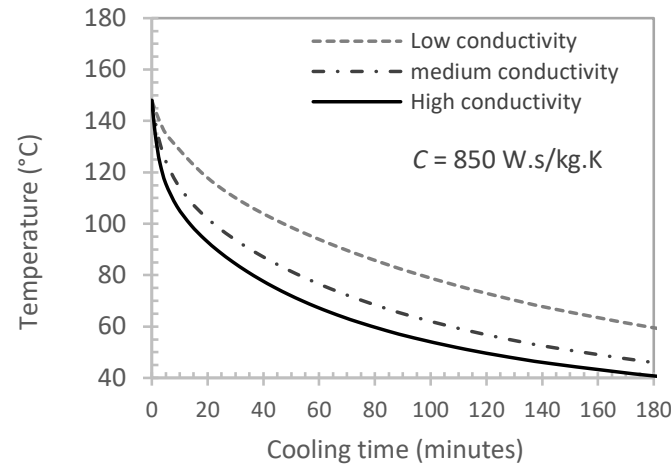

(a)

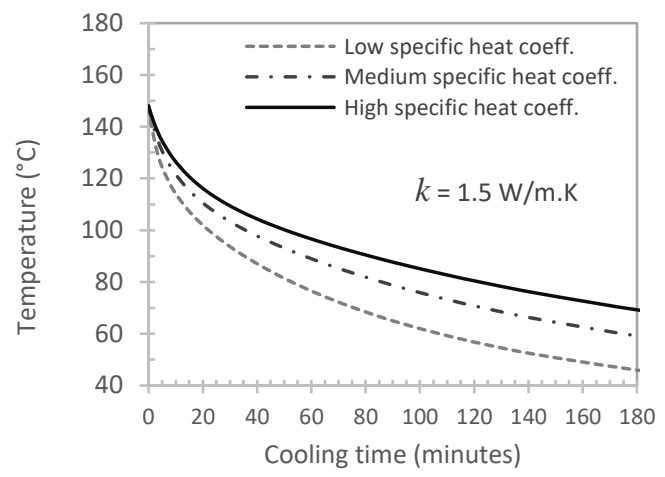

(b)

Figure 8. Temperatures at bottom of newly laid asphalt, (a) for various material's heat conductivity; (b) material's specific heat coefficient.

\section{(4) Decreasing the pavement temperature by spraying water onto the new asphalt}

In tropical countries, where the ambient temperature is high (exceeding $30^{\circ} \mathrm{C}$ ), the temperature drops slowly, so the cooling time would be very lengthy to reach a targeted temperature. Some contractors practice spraying water on the newly laid asphalt to speed up the cooling time. However, there is no specific research regarding the effect of water spraying to a new asphalt surface. It is not recommended by the Asphalt Institute (2009) as there is a concern that hot asphalt binder would experience a foaming effect. Spraying water on the asphalt is also predicted to be ineffective, it would only cool the asphalt surface temporarily, while the temperature inside the asphalt would not be much affected.

In this section, water spray cooling is represented by the convective heat transfer coefficient on the pavement surface and input to the model in ABAQUS program. The scheme (Figure 9) of spraying water onto newly laid asphalt overlay is characterized by spraying water at a temperature $T_{W}$ and flow rate $V_{W}$ towards the surface to be cooled. It is well known from the literature that the temperature of the water $T_{W}$ influences the rate of cooling (Bamberger and Prinz, 1986). The other important parameters is the temperature of the surface $T_{S}$ and the water flow $V_{W}$ (Wendelstorf et al., 2008). Note that any latent heat effects are ignored so the results of the calculation will under-estimate the benefit.

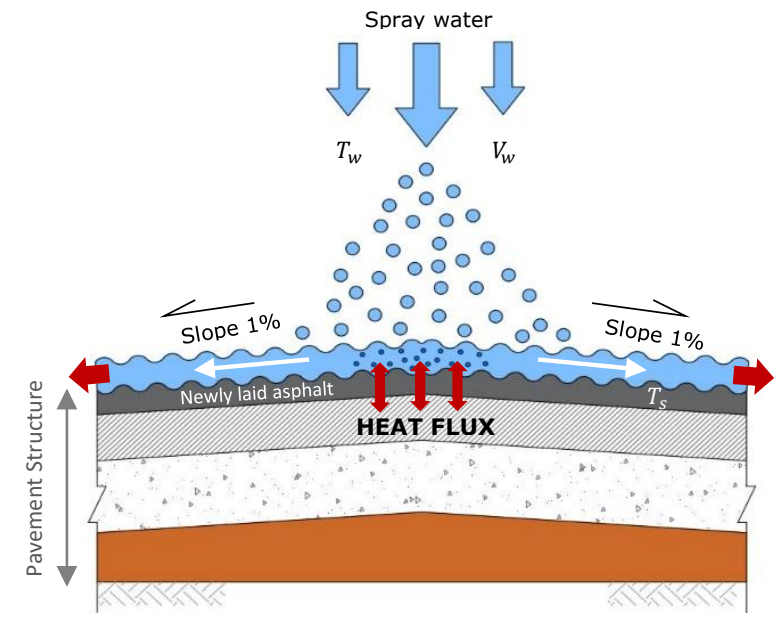

Figure 9. Spray water cooling scheme. 
An empirical equation (7) to determine heat transfer coefficients $\left(h_{\text {spray }}\right)$ during water cooling of metals, as developed by Bamberger and Prinz (1986), is adopted here:

$$
h_{\text {spray }}=0.69 \log \frac{V_{w}}{0.0006}\left[1.4 \sqrt{(k \rho C) \exp \left(0.32 \frac{T_{s}-T_{e}}{T_{w}-T_{e}}\right)+h_{v}}\right]+h_{\text {rad }}
$$

where $k=$ thermal conductivity of the asphalt $(\mathrm{W} / \mathrm{m} \mathrm{K}) ; \rho=$ density of the asphalt $\left(\mathrm{kg} / \mathrm{m}^{3}\right) ; C=$ specific heat of the asphalt $(\mathrm{J} / \mathrm{kg} \mathrm{K}) ; T_{S}=$ surface temperature of the asphalt $(\mathrm{K}) ; T_{e}=$ evaporation temperature of water $(\mathrm{K}) ; T_{w}=$ initial bulk temperature of the water $(\mathrm{K}) ; T_{A}=$ ambient temperature $(\mathrm{K}) ; h_{v}=$ heat transfer coefficient for stable film evaporation at high surface temperature $\left(\approx 750 \mathrm{~W} / \mathrm{m}^{2} \mathrm{~K}\right) ; h_{\text {rad }}=$ heat transfer coefficient for radiation $\left(\mathrm{W} / \mathrm{m}^{2} \mathrm{~K}\right) ; \sigma=$ Stefan-Boltzmann constant $\left(5.67 \times 10^{-8} \mathrm{~W} / \mathrm{m}^{2}\right.$ $\left.\mathrm{K}^{4}\right) ; \varepsilon=$ emissivity; $V_{w}=$ water flux density, $\mathrm{m}^{3} / \mathrm{m}^{2} \mathrm{~s}$; and $h_{\text {rad }}$ as given by:

$$
h_{\text {rad }}=\sigma \varepsilon \frac{T_{e}^{4}-T_{A}^{4}}{T_{e}-T_{A}}
$$

The heat transfer coefficients achieved by spray water at 10 and $30^{\circ} \mathrm{C}$ for various spray flows, calculated using equation (7), are shown by the lines in Figure 10.

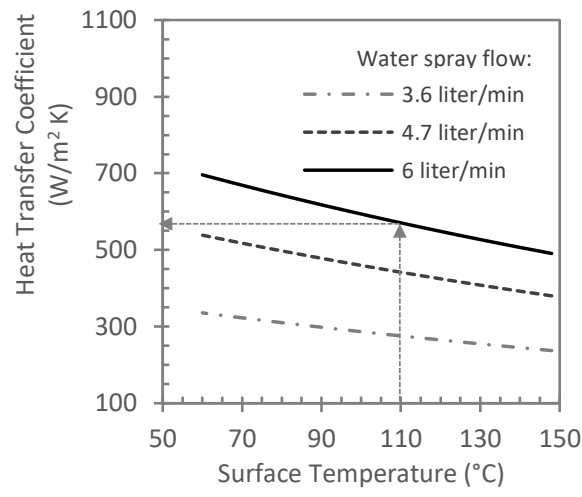

(a)

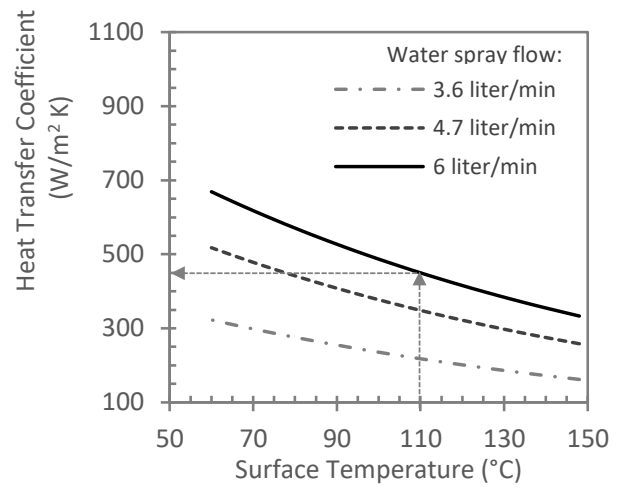

(b)

Figure 10. Heat transfer coefficient as a function of surface temperature with an initial water spray temperature of (a) $10{ }^{\circ} \mathbf{C}$; (b) $30{ }^{\circ} \mathrm{C}$ (dotted line explained in text)

As expected, there is an increase in the heat transfer coefficient with an increase of the spray flow rate (Figure 10). The coefficient of heat transfer from newly laid asphalt to water reduces with the increase of initial temperature of water - see dotted lines for (e.g.) asphalt at $110^{\circ} \mathrm{C}$ in Figure 10 . The amplitude of selected spray water heat transfer coefficients is assumed varied over the entire simulation period. An exponential decay equation is chosen to model the reduction of the heat transfer coefficient with time as the sprayed water now slowly flowing across the asphalt surface warms up. It is assumed that the largest value of heat transfer coefficient occurs when water is sprayed, and then, it gradually decreases as the water flows to the pavement drains (due to the pavement cross-fall). Figure 11 is the variation of heat transfer coefficient amplitude with time used in this research, where the water spraying is assumed to be applied 30 minutes $\left(t_{o}\right)$ after asphalt placement. Moreover, it is assumed that the temperature of water $T_{W}$ is $10^{\circ} \mathrm{C}$, and the decay time is 5 minutes. An analysis to compare the cooling time of asphalt with natural cooling, and forced cooling (using spray water) is performed. The result of this analysis is shown in Figure 12.

From Figure 12, it can be seen that the cooling time of newly laid of asphalt is the same in the first 30 minutes. When water is sprayed, it reveals that the temperature at 
the asphalt surface drops drastically to reach the water temperature and then gradually rises to ambient temperature as the water flows. Surprisingly, the temperature at the middle and the bottom of the newly laid asphalt is also considerably affected. When $60^{\circ} \mathrm{C}$ is set as the maximum asphalt temperature for opening to traffic, the predicted cooling time at the bottom of asphalt mat is 71 minutes when spray water is applied and 107 minutes for asphalt with natural cooling. It can be concluded that the heat loss is greatly affected by water cooling; therefore, the use of spray water considerably reduces the required cooling time. However, different temperatures, flow, and travel time of water would result in different water cooling responses of asphalt.
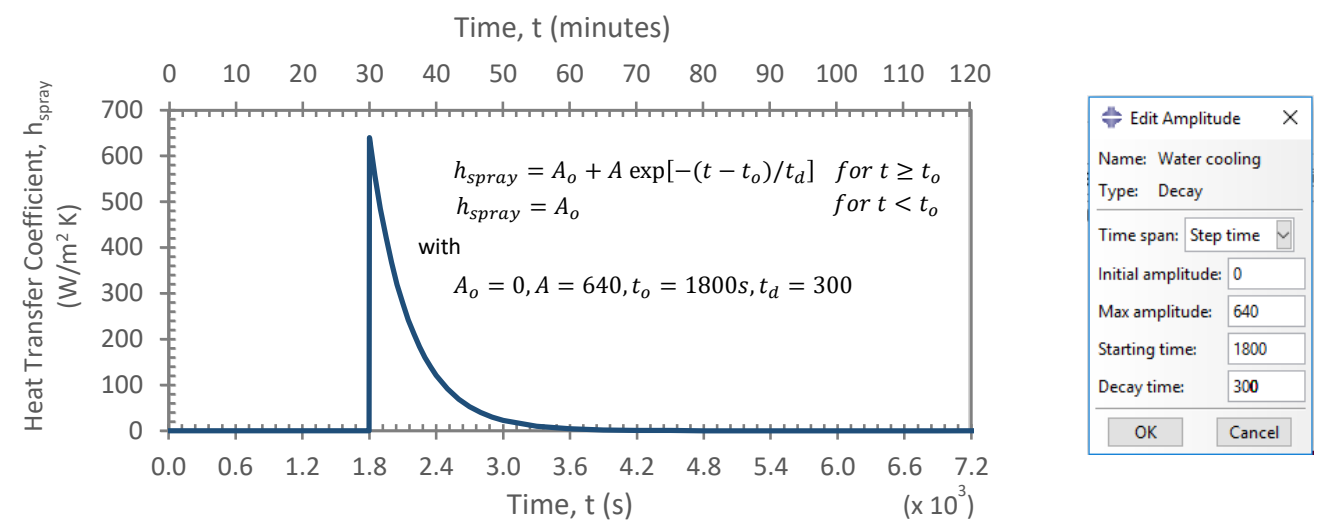

Figure 11. Exponential decay amplitude of heat transfer coefficient of water cooling.

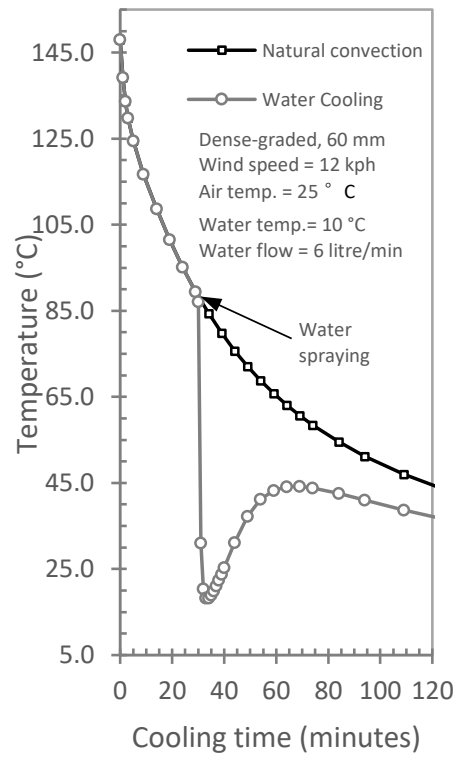

(a)

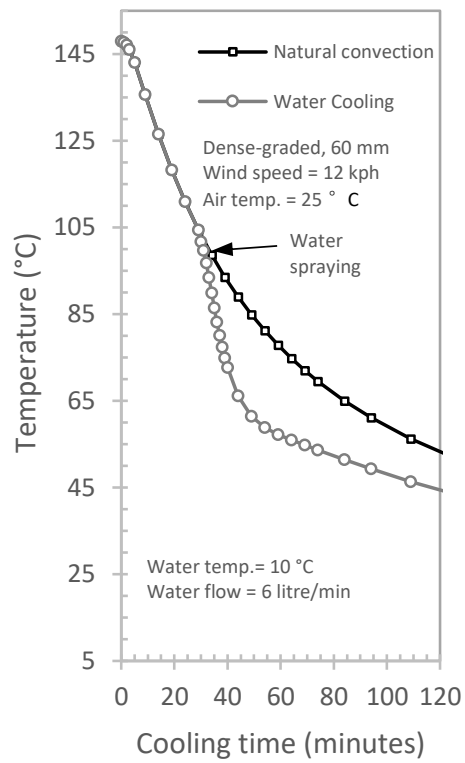

(b)

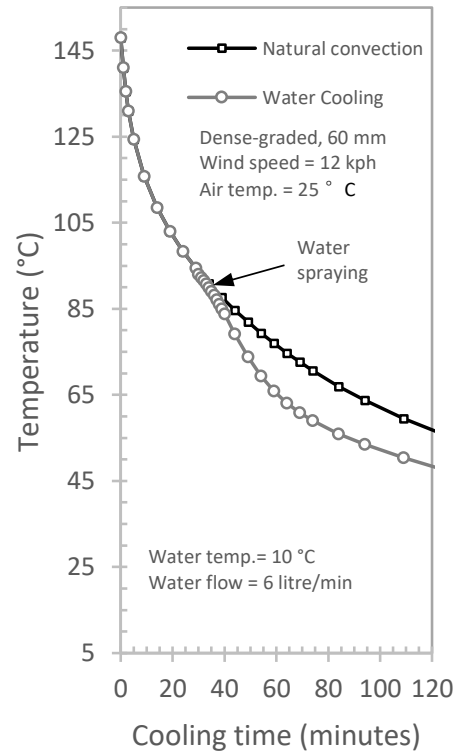

(c)

Figure 12. Cooling curve of newly laid of asphalt pavement for natural convection and spray water cooling at (a) top; (b) mid-depth; (c) bottom of asphalt overlay.

Regardless of its benefit in reducing the cooling time of asphalt, there are limited research and guidance related to water spraying application for asphalt cooling. It is hypothesized that the water spraying could lead to particular detrimental impact, including long-term durability damage of the asphalt. 


\section{CONCLUSION AND DISCUSSION}

Freshly placed asphalt must be sufficiently cooled before it can be opened to air traffic. Reduced cooling time will help airport authorities to quickly open new pavements and allow paving crews to pave a maximum area with asphalt each night. Several strategies for reduced cooling time have been proposed and analysed using a thermal FE approach. The results show that each strategy significantly contributes to the rapid cooling of newly laid asphalt. The predicted cooling times, until reaching a permissible trafficking temperature of $60^{\circ} \mathrm{C}$, are presented in Table 7 . However, there are some concerns over the performance of the pavements when such cooling strategies are adopted. Permanent deformation (rutting) and shear failure (delamination) could occur when newly laid asphalt pavement is opened to traffic at too high a temperature. Furthermore, concerns still exist when WMA is used to replace HMA, particularly with respect to rutting and moisture susceptibility. In addition, the long-term durability of asphalt that has been cooled by water spraying also needs to be investigated. In airfield pavements, where safety is critically important, these distresses should be avoided. Where it occurs, it could be dangerous for aircraft operations.

Table 7. Predicted cooling time of newly laid asphalt to cool down to $60^{\circ} \mathrm{C}$ (at Bottom of layer) for various strategies

\begin{tabular}{|c|c|c|c|}
\hline Strategy & Sub-strategy & \begin{tabular}{|c|} 
Cooling \\
time (min)
\end{tabular} & $\begin{array}{c}\text { Possible drawbacks/ } \\
\text { challenges }\end{array}$ \\
\hline No strategy & $60^{\circ} \mathrm{C}$ at opening to traffic & 107 & - \\
\hline \multirow{2}{*}{$\begin{array}{l}\text { 1. Selecting warmest } \\
\text { temperature for trafficking }\end{array}$} & $85^{\circ} \mathrm{C}$ at opening to traffic & 44 & \multirow{2}{*}{$\begin{array}{l}\text { Premature failure of asphalt; } \\
\text { depends on mixes }\end{array}$} \\
\hline & $70^{\circ} \mathrm{C}$ at opening to traffic & 76 & \\
\hline \multirow{2}{*}{$\begin{array}{l}\text { 2. Using warm mix asphalt } \\
\text { (WMA) }\end{array}$} & Initial temp. $130^{\circ} \mathrm{C}$ & 86 & \multirow{2}{*}{$\begin{array}{l}\text { Rutting and moisture } \\
\text { susceptibility }\end{array}$} \\
\hline & Initial temp. $118^{\circ} \mathrm{C}$ & 71 & \\
\hline $\begin{array}{l}\text { 3. High thermal conductivity } \\
\text { of mixture }\end{array}$ & $\operatorname{High}(2.8 \mathrm{~W} / \mathrm{K} . \mathrm{m})$ & 79 & $\begin{array}{l}\text { Higher cost when admixture and } \\
\text { aggregate is not available }\end{array}$ \\
\hline \multirow[t]{2}{*}{ 4. Spray water cooling } & Water temperature: $10^{\circ} \mathrm{C}$ & 71 & \multirow{2}{*}{$\begin{array}{l}\text { - long-term durability of asphalt } \\
\text { is still questionable } \\
\text { - Higher cost when cold water is } \\
\text { not available }\end{array}$} \\
\hline & Water temperature: $30^{\circ} \mathrm{C}$ & 88 & \\
\hline
\end{tabular}

\section{ACKNOWLEDGEMENTS}

The authors thank LPDP (Indonesia Endowment Fund for Education), Ministry of Finance, Republic of Indonesia for providing financial support for the study.

\section{REFERENCES}

Aho, B., Hein, D., Dennechuk, S. \& Bessom, R. (2016). 10 Years of Experience Using Warm Mix Asphalt for Airside Pavements-Boston Logan Airport. Int'l Conf. Transportation \& Development 2016.

Asphalt Institute. (2009, December 2). Asphalt Pavement Construction FAQs [Online]. Available: http://www.asphaltinstitute.org/asphalt-pavement-construction-faqs/.

Bamberger, M. \& Prinz, B. (1986). "Determination of heat transfer coefficients during water cooling of metals". Materials Science \& Technology, 2, 410-415.

Bergman, T. L., Incropera, F. P., DeWitt, D. P. \& Lavine, A. S. (2011). Fundamentals of heat and mass transfer, John Wiley \& Sons.

Chadbourn, B. A., Newcomb, D., Voller, V., Desombre, R. A., Luoma, J. A. \& Timm, D. H. (1998). "An asphalt paving tool for adverse conditions", MnRoad report MN/RC 1998-18 
Côté, J. \& Konrad, J.-M. (2005). "Thermal conductivity of base-course materials". Canadian Geotechnical J., 42, 61-78.

Dawson, A. R., Dehdezi, P. K., Hall, M. R., Wang, J. \& Isola, R. (2012). "Enhancing thermal properties of asphalt materials for heat storage and transfer applications". Road Materials \& Pavement Design, 13, 784-803.

FAA (2006). Off-peak Construction of Airport Pavements Using Hot-Mix Asphalt, AC 150/5370-13A. Washington, DC.

Frank, J. E., Fuselier, G. K., Decker, C. S. \& Thuma, R. G. (2013). Resurfacing the Runway to the Nation's Capital. Airfield and Highway Pavement 2013: Sustainable and Efficient Pavements.

Hachiya, Y., Su, K., Motono, I., Muranaga, T., Kajitani, A. \& Kano, T. (2008). Implementing overnight asphalt inlay work on working runway. Proc. 4th Eurasphalt and Eurobitume Congress, Copenhagen, Denmark.

Hall, M. R., Dehdezi, P. K., Dawson, A. R., Grenfell, J. \& Isola, R. (2012). "Influence of the Thermophysical Properties of Pavement Materials on the Evolution of Temperature Depth Profiles in Different Climatic Regions". J. Materials in Civil Eng'g, 24, 32-47.

Han, R., Jin, X. \& Glover, C. J. (2011). "Modeling Pavement Temperature for Use in Binder Oxidation Models and Pavement Performance Prediction". J. Materials in Civil Eng'g, 23, 351-359.

Hermansson, ^. (2004). "Mathematical model for paved surface summer and winter temperature: comparison of calculated and measured temperatures". Cold Regions Science \& Technology, 40, 1-17.

Lytton, R. L., Tsai, F.-L., Lee, S. I., Luo, R., Hu, S. \& Zhou, F. (2010). Models for predicting reflection cracking of hot-mix asphalt overlays. NCHRP Report 669.

Mrawira, D. \& Luca, J. (2006). "Effect of aggregate type, gradation, and compaction level on thermal properties of hot-mix asphalts". Canadian J. of Civil Eng'g, 33, 1410-1417.

Rohsenow, W. M., Hartnett, J. P. \& Cho, Y. I. (1998). Handbook of Heat Transfer, McGrawHill.

Solaimanian, M. \& Kennedy, T. W. (1993). "Predicting maximum pavement surface temperature using maximum air temperature and hourly solar radiation". Transportation Research Record, No. 1417, 1-11.

Su, K., Maekawa, R. \& Hachiya, Y. (2009). "Laboratory evaluation of WMA mixture for use in airport pavement rehabilitation". Construction \& Building Mat's, 23, 2709-2714.

Wang, Y., Zhu, S. \& Wong, A. S. T. (2014). "Cooling Time Estimation of Newly Placed HotMix Asphalt Pavement in Different Weather Conditions". J. Construction Eng'g \& Management, 140, 04014009.

Wendelstorf, J., Spitzer, K. H. \& Wendelstorf, R. (2008). "Spray water cooling heat transfer at high temperatures and liquid mass fluxes". Int'l J. Heat \& Mass Transfer, 51, 49024910.

West, R., Rodezno, C., Julian, G., Prowell, B., Frank, B., Osborn, L. \& Kriech, T. (2014). " Field Performance of Warm Mix Asphalt Technologies". NCHRP Report 779.

White, G. (2017). Expedient runway upgrade technologies. In: LOIZOS, A., ALQADI, I. \& SCARPAS, T. (eds.) 10th Int'l Conf Bearing Capacity of Roads, Railways \& Airfields. Athens, Greece: Taylor \& Francis Group.

Wills, W. (1982). Current Practices on Nighttime Pavement Construction Asphaltic Concrete. US Department of Transportation, Federal Aviation Administration.

Zapata, C. E. \& Houston, W. N. (2008). Calibration and validation of the enhanced integrated climatic model for pavement design, Transportation Research Board. 